\title{
輪荷重の反復作用下での道路橋 RC 床版の低サイクル疲労特性 \\ LOW CYCLE FATIGUE CHARACTERISTICS OF BRIDGE DECK RC SLABS UNDER THE REPETITION OF WHEEL LOADS
}

\author{
園田恵一郎* · 堀川都志雄 ${ }^{* *}$ \\ By Keiichiro SONODA and Toshio HORIKAWA
}

\begin{abstract}
A total of 47 model slabs whose scale was about $1 / 3$ to a typical deck panel between adjacent main girders of an existing steel-concrete composite girder bridge were tested under the repetition of a wheel load using a wheel tracking machine originally developed by Osaka City University. The tests were confined with a low cycle fatigue range in which the repetition of a wheel load was less than $2 \times 10^{4}$ times. The numerous data obtained in the tests are used to reveal the low cycle fatigue characteristics of bridge deck RC slabs. Besides, assuming that such characteristics may also significantly control the high cycle characteristics of the slabs, a method for estimating fatigue strength and fatigue life of bridge deck RC slabs is proposed.
\end{abstract}

Keywords: bridge deck, fatigue, low cycle fatigue, RC slab, cracking, ultimate strength, design equation

\section{1. 緒言}

周知のように，昭和 40 年頃より鋼析橋の $\mathrm{RC}$ 床版の ひびわれ損傷問題がクローズアップされて以来, 道路を 管理する諸官庁の技術者や構造およびコンクリートを専 門とする研究者によって多方面からひびわれ損傷の原因
究明や対策についての調查・研究がなされてきた. 著者 も昭和 50 年頃よりこの問題に興味をもち，実験および 理論的な研究成果のいくつかを発表してきた ${ }^{2) \sim 5}$. これ らの成果の中心は， RC 床版のひびわれ損傷は広義の疲 労現象であり,この現象は自動車荷重特有の荷重の移 動・繰返しに大きく起因すると結論したことである.す

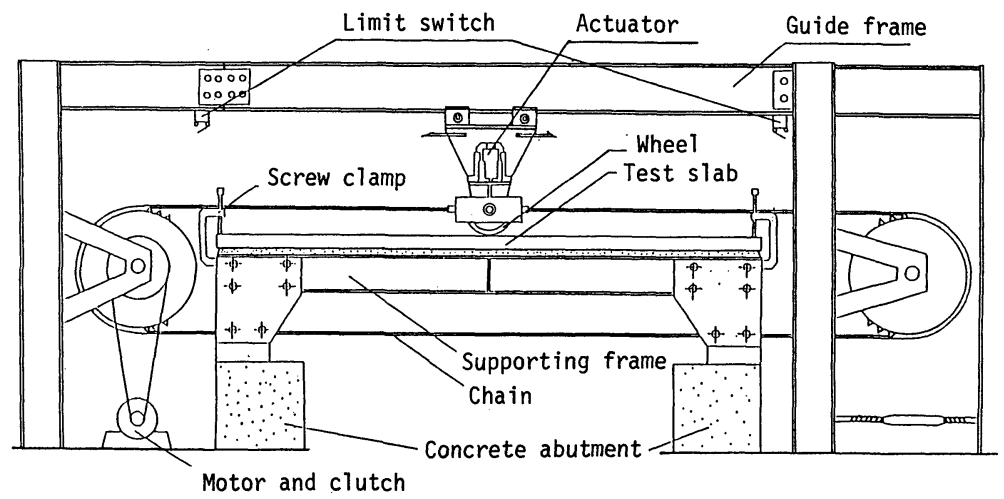

図一1実験装置の概観

* 正会員 工博 大阪市立大学教授 工学部土木工学科 ( ₹558 大阪市住吉区杉本 3-3-138)

** 正会員 工博 大阪工業大学講師 工学部土木工学科 （テ535 大阪市旭区大宮 5-16-1） 
なわち，許容応力度法に基づく $\mathrm{RC}$ 床版の設計におい ては, 荷重の移動は影響面を利用して最大曲げモーメン トの決定にのみ考慮されているが, ひびわれ床版の力学 的応答は線形ではなく, 荷重の移動による変動する組合 せ応力の反復作用はひびわれ面の磨耗とひびわれ端の進 展を促し, 比較的低荷重の下でも $\mathrm{RC}$ 床版は疲労破壊 し得ることを指摘した. しかしながらここれらの知見は あくまでも定性的なもので, 定量化し設計へ反映するに はいまだ至っていないのが現状である.

$\mathrm{RC}$ 床版は鋼とコンクリートの合成構造で，その疲労 特性に与える要因は鋼とコンクリートの素材の強度之付 着強度, 乾燥収縮によるコンクリートの内在ひびわれの 程度ならびに施工状態など多岐にわたっており， RC 床 版の疲労強度を定量的にとらえることは非常に困難であ る. しかしながら，いくつかの実橋床版の損傷状況を調 べると, 乾燥収縮によるコンクリートの初期ひびわれに 加えて過積載の自動車の反復走行が $\mathrm{RC}$ 床版の疲労に 与える最も大きい要因と推測できる ${ }^{5), 6)}$.

以上の背景の下に, 本研究は $\mathrm{RC}$ 床版の曲げひびわ れ損傷過程の究明を目的とし, 典型的な鋼析橋における 隣接主析間の床版の約 $1 / 3$ のスケールのモデルに対し て, 新たに開発した輪荷重装置により，104回程度の走 行を限度とした低サイクル疲労実験を行い, ひびわれの 進展, 鉄筋応力の変化, たわみの増大などに与える荷重 と走行回数ならびにスパンや配筋方法の影響を調査し た.さらに, 道路橋 $\mathrm{RC}$ 床版では, 過積載の自動車の 走行がひびわれ損傷に支配的であると考え，本実験で得 た知見から道路橋 $\mathrm{RC}$ 床版の疲労強度推定法を検討し た.

\section{2. 低サイクル疲労実験}

\section{（1）輪荷重装置}

本実験は昭和 57 年から 61 年にかけて行われた。実験 装置の概要を図一1，2に示す. 図一1 は全体図で実験床 版は周辺で支持フレームに単純支持されている. 輪荷重 部は油圧ジャッキ(アクチュエーターともよぶ) とポリ ウレタンゴム（厚さ $20 \mathrm{~mm}$ ) を巻きつけた鋼製車輪（直 径 $30 \mathrm{~cm}$ ）から成り, 輪荷重部はウインチによって引張 られ, 左右端のリミットスイッチからの信号によってウ インチの電磁クラッチを切換え, 輪荷重は左右に反復走 行するようになっている. 走行中の荷重の大きさを一定 に保つための装置としては, 初期の段階（昭和 57 年 60 年）では, カウンターウエイト方式，すなわち輪荷 重部の油圧ジャッキ（圧縮）と一定の重鍾を吊した引張 油圧ジャッキを高圧ゴム管で連絡し, 油圧ポンプからオ イルを充填した後に弁を閉じて連通管とし, パスカルの 原理により, 両ジャッキのピストンの受圧面積比で倍増

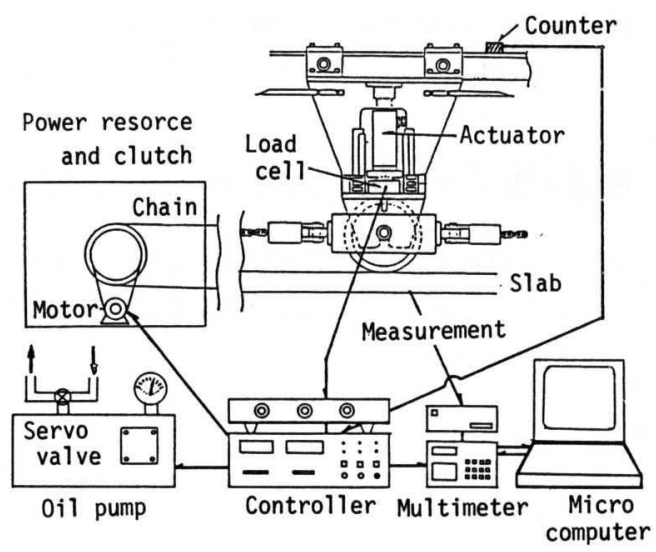

図一2 油圧サーボ方式と自動計測システム

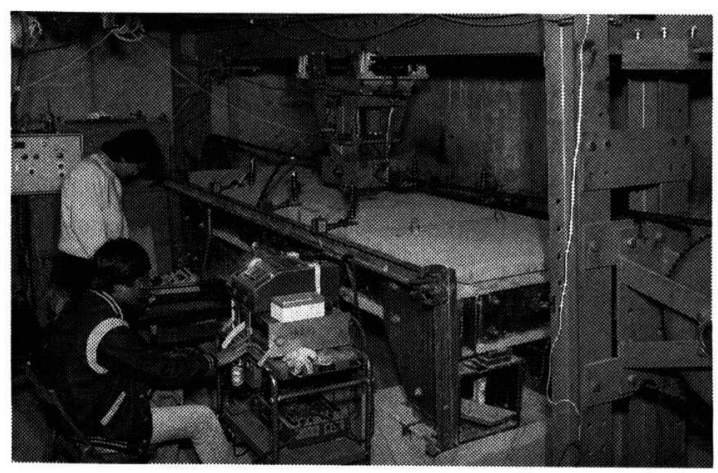

写真一1 実験風景

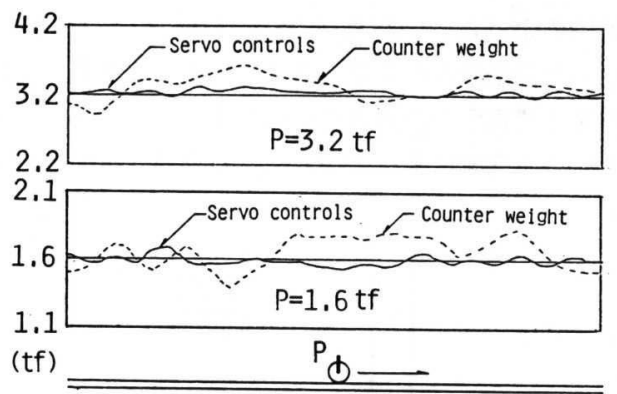

図一3 荷重の変動特性

させた荷重を車輪に与える方式であった.しかしながら， この方式では重鍾の慣性力やゴム管内のオイルの粘性な どの影響を受け，図一3に示すように，一定荷重の制御 には精度的に限界があった. その後 (昭和 60 年 61 年), 一定荷重の制御は油圧サーボ方式に変え, 計測の自動化 と自動運転を図るためのマイクロコンピュータによる制 御・計測システム（図一2）を採用した。これにより一 定荷重の制御は図一3に示すように格段に改善された. なお, 輪荷重の走行速度は約 $10 \mathrm{~m} /$ 分である.

（2）実験床版の諸元 
表一1＼cjkstart実験床版の諸元

\begin{tabular}{|c|c|c|c|c|c|c|c|c|c|}
\hline \multirow[t]{2}{*}{ 名 称 } & \multirow[t]{2}{*}{ 枚数 } & \multirow{2}{*}{$\begin{array}{c}\text { 寸 法 } \\
(\min \times \text { mini })\end{array}$} & \multirow{2}{*}{ (板) } & \multicolumn{2}{|c|}{$\begin{array}{l}\text { 有効高さ } \\
\text { (man) }\end{array}$} & \multicolumn{2}{|c|}{ 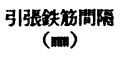 } & \multicolumn{2}{|c|}{ 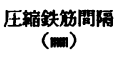 } \\
\hline & & & & 主第 & 酶力節 & 主第 & 配力䈍 & 主箉 & 配力第 \\
\hline I S & 6 & $900 \times 3100$ & 72 & 62 & 56 & 50 & 50 & - & - \\
\hline I S S & 6 & & 75 & 65 & 59 & 50 & 50 & - & - \\
\hline I R & 6 & " & 72 & 62 & 56 & 50 & 50 & 100 & 100 \\
\hline I D & 6 & " & $"$ & " & " & 50 & 50 & 50 & 50 \\
\hline os & 4 & " & " & " & $"$ & 50 & 100 & - & - \\
\hline OR & 3 & " & $"$ & " & " & 50 & 100 & 100 & 200 \\
\hline NOS & 4 & " & 70 & 60 & 54 & 50 & 70 & - & - \\
\hline NOR & 8 & " & " & " & " & 50 & 70 & 100 & 140 \\
\hline NWR & 4 & $1100 \times 3100$ & $"$ & $"$ & " & 50 & 70 & 100 & 140 \\
\hline
\end{tabular}

\begin{tabular}{|c|c|c|c|c|c|}
\hline \multirow[b]{2}{*}{ 供栻体 } & \multicolumn{2}{|c|}{ 笂筇(D6) } & \multicolumn{3}{|c|}{ コンクリート } \\
\hline & $\begin{array}{c}\text { 绦伏点 } \\
\left(\mathrm{kgf} / \mathrm{cm}^{2}\right)\end{array}$ & $\begin{array}{c}\text { 势張強度 } \\
\left(\mathrm{kgf} / \mathrm{cm}^{2}\right)\end{array}$ & $\begin{array}{l}\text { 压縮強度 } \\
\left(\mathrm{kgf} / \mathrm{cm}^{2}\right)\end{array}$ & $\begin{array}{l}\text { 引張強度 } \\
\left(\mathrm{kgf} / \mathrm{cm}^{2}\right)\end{array}$ & 借考 \\
\hline $\begin{array}{c}\text { IS,IR, ID } \\
\text { OS, } 0 R\end{array}$ & $3700^{*}$ & $5700^{*}$ & 478 & 37 & $\begin{array}{l}\text { 材令70日 } \\
8 \text { 月打没 }\end{array}$ \\
\hline ISS & 4758 & 6450 & 198 & 19 & 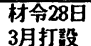 \\
\hline NOS, NOR & 3800 & 5500 & 221 & 21 & $\begin{array}{l}\text { 材令28日 } \\
11 \text { 月打教 }\end{array}$ \\
\hline NUR & 3800 & 5500 & 232 & 21 & 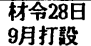 \\
\hline
\end{tabular}

（注）*䓡处理済

\begin{tabular}{|c|c|c|c|c|c|}
\hline \multicolumn{2}{|r|}{ 表-3 } & ンク & 足 & & \\
\hline $\begin{array}{c}\text { 最大骨等材法 } \\
(\mathrm{mm})\end{array}$ & $\begin{array}{c}\text { スランブ } \\
(\mathrm{cm})\end{array}$ & $\begin{array}{l}\text { 空気重 } \\
(\text { ( ) }\end{array}$ & $\begin{array}{l}\text { W/SEE } \\
(\%)\end{array}$ & $\begin{array}{l}\mathrm{s} / \mathrm{a} \\
(\%)\end{array}$ & $\begin{array}{c}\begin{array}{c}\text { 単位セメント量 } \\
\left(\mathrm{kg} / \mathrm{m}^{3}\right)\end{array} \\
\end{array}$ \\
\hline $15^{*}$ & $10 \sim 22$ & $3 \sim 5$ & 50 & 47 & 370 \\
\hline
\end{tabular}

（注）*供試体 I S Sのみ10mm

実験に用いた床版（以下，供試体とよぶ）の種類と数 を表一1 に示す。供試体 IS，ISS，IR，ID，OS，OR は初期の段階の実験で前述のカウンターウエイト方式に よる一定荷重装置を用いており，供試体 NOS，NOR， NWR は油圧サーボ方式を用いている，各供試体は 4 つ の時期に分けて製作された．鉄筋はすべて D 6 で，コ イル状のものから伸線されており，その強度を表一2に 示す.コンクリートはいずれの時期においても同じ配合 設計（表一3）で打設したが，強度は大きく異なってい た（表一2）．実験はかなり長期にわたり，同一時期の供 試体で最大 6 か月間を要した。したがってこの間，コン クリートの強度は多少の変化があるものと思われる.

各供試体の製作はコンクリート製品会社に依頼した。 床版厚 $70 \mathrm{~mm}$ を目標としたが，製作の関係上表一1 の ように出来上がった，配筋については，主筋の中心から 床版下面までの距離を $10 \mathrm{~mm}$ とし，配力筋は主筋の上 に乗せた．したがって，主筋間隔と配筋間隔が同じでも 厳密には曲げ強度に関して等方性ではない。

\section{（3）実験方法}

図一1に示したように，供試体は支持フレームに乗せ， 四隅の浮き上がりは万力で防止している．図一4 は供試 体の支持と輪荷重の走行位置を示す．短スパンは $80 \mathrm{~cm}$ (ただし，NWR は $100 \mathrm{~cm}$ )，長スパンは $3 \mathrm{~m}$ であり， 一方向スラブとみなせる形状を有している．周辺の単純
支持をできる限り正確に実現するために，支持フレーム の上に溶接した丸鋼棒 (直径 $25 \mathrm{~mm}$ ) の上に, フレッシュ モルタルを覆い，硬化前に供試体をのせ，硬化後に支持 線上の隙間がなくなるようにした。

荷重の走行位置は，図一4に示すように，中央部 2.3 $\mathrm{m}$ である.ポリウレタンゴム (JIS 硬度 95) 製タイヤ を介した輪荷重の接地面 $(u \times v)$ は荷重の大きさにつ れて進行方向に変化し，低荷重時 $(1.7 \mathrm{tf})$ で $15 \mathrm{~cm} \times 3$ $\mathrm{cm}$, 高荷重時 $(5.6 \mathrm{tf})$ で $15 \mathrm{~cm} \times 5 \mathrm{~cm}$, 静的破壊時で $15 \mathrm{~cm} \times 8 \mathrm{~cm}$ 程度であった. 走行中の荷重の変動率につ いては，すでに触れたが，カウンターウエイト方式では 大きく，荷重が大きい場合で， $\pm 10 \%$ ，荷重が小さい 場合で， $\pm 20 \%$ 程度の変動率があり，油圧サーボ方式 では， $\pm 5 \%$ 以内の変動率におさまった。

\section{（4）載荷プログラム}

本供試体を道路橋 $\mathrm{RC}$ 床版のモデルとみなせば，設 計荷重に相当する荷重は，床版中央に輪荷重を静止させ たときの主筋に作用する最大応力が許容引張応力（ $\sigma_{s a}$ $\left.=1400 \mathrm{kgf} / \mathrm{cm}^{2}\right)$ になる荷重の大きさと定義できる. 弾性薄板理論により, 荷重 $P$ と最大曲げモーメントと の関係を求めれば,

$$
\max M_{x}=k P \cdots
$$

$k$ は輪荷重の接地面に依存する係数であり，短スパンが $80 \mathrm{~cm}$ の場合, $15 \mathrm{~cm} \times 3 \mathrm{~cm}$ で $k=0.266,15 \mathrm{~cm} \times 5 \mathrm{~cm}$ で $k=0.263$ であった. 一方，通常の $\mathrm{RC}$ ばりの計算法 により，鉄筋の引張応力が $\sigma_{s a}$ になるときの抵抗モーメ ントを求め, 設計荷重相当値 $\left(P_{d}\right)$ を計算すれば，供 試体 ISS で $P_{d}=2.1 \mathrm{tf}$, 供試体 NWR で $P_{d}=1.6 \mathrm{tf}$, そ の他の供試体で $P_{d}=1.7 \mathrm{tf}$ となった，疲労実験での輪 荷重の大きさは $P_{d}$ を下限値とし，それに一定の係数を かけた值にとった．輪荷重の走行回数は $1 \times 10^{4} \sim 2 \times 10^{4}$ を限度とし，この回数で破壊しない場合は荷重を増加さ せて破壊するまで実験を継続した。

\section{(5) 実験結果}

a) 静的実験

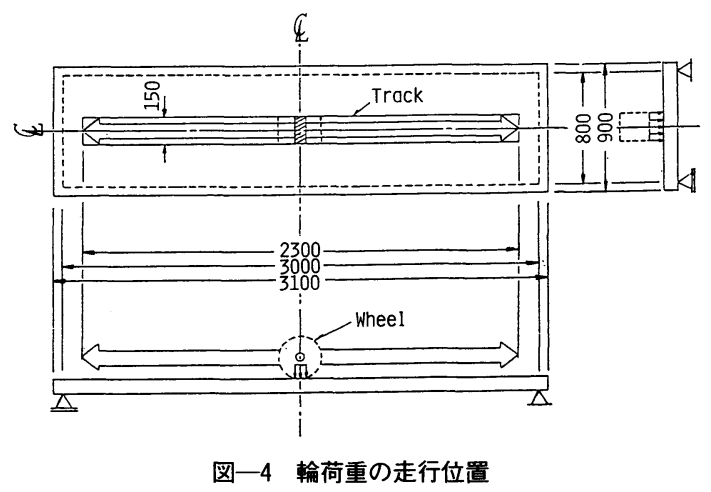


静的破壊実験は最初に車輪を床版の中央に固定して実 施した．破壊形式はすべて押抜きせん断形であり，破壊 箇所は載荷面近傍に限られていたので，同じ供試体に対 して, 中央点とそれから長辺方向に $90 \mathrm{~cm}$ だけ離れた 2 点での実験も行った．得られた破壊荷重の大きさを表 -4に示す．破壊モードの一例を図一 5 に示すが，典型 的な押抜きせん断形であったが，荷重点直下の鉄筋ひず みは降伏ひずみをかなり越えた後に破壊に至った．表一 4 にはコンクリート標準示方書 ${ }^{1}$ による押抜きせん断荷 重の計算值も示している.

初期ひびわれは荷重面直下の床版下面で配力筋と平行 に入り，目視によるひびわれの発生荷重は供試体 ISS で $2.0 \mathrm{tf}, \mathrm{NOR}$ とWS で $1.0 \mathrm{tf}$ ，その他で $1.5 \mathrm{tf}$ であ り，主筋に平行なひびわれも次の荷重段階（増分間隔は $0.5 \mathrm{tf})$ で確認された。

床版中央点での荷重・たわみ曲線を図一6に示す．設 計荷重相当值 $\left(P_{d}\right)$ の下でのたわみの全断面有効とし たときの弾性薄板理論値（弾性係数は $2 \times 10^{5} \mathrm{kgf} / \mathrm{cm}^{2}$ と仮定（図中の(1)）は $0.28 \sim 0.31 \mathrm{~mm}$ であり, 引張コ ンクリート部を無視したときの同様の理論値(図中の(2) は全断面有効時の約 3 倍になっていた.

b) 輪荷重走行実験

(1) 疲労耐力

合計 35 の供試体に対する輪荷重走行実験の結果, 破 壊に至ったときの荷重 $(P)$ と走行回数 $(N)$ の関係を

\begin{tabular}{|c|c|c|c|c|c|}
\hline \multirow{2}{*}{ 供試体 } & \multicolumn{4}{|c|}{ 破壊荷重(tf) } & \multirow{2}{*}{ 計算值 $^{*}$} \\
\hline & $+90 \mathrm{~cm}$ & 中央点 & $-90 \mathrm{~cm}$ & 平均值 & \\
\hline I S & 10.7 & 11.0 & 10.5 & 10.7 & 13.2 \\
\hline I $\mathrm{R}$ & 10.0 & 10.5 & 10.3 & 10.3 & 13.2 \\
\hline I D & 11.8 & 12.4 & 13.0 & 12.4 & 13.2 \\
\hline $0 \mathrm{~S}$ & 10.1 & 10.5 & 10.1 & 10.2 & 12.4 \\
\hline OR & 7.8 & 7.8 & 7.9 & 7.8 & 12.4 \\
\hline I S S & 13.2 & 13.5 & 14.3 & 13.7 & 8.6 \\
\hline NOS & 9.6 & 9.7 & 9.1 & 9.5 & 8.3 \\
\hline NOR & 9.8 & 9.9 & 10.1 & 9.4 & 8.3 \\
\hline NWR & 10.0 & 9.5 & 9.4 & 9.6 & 8.5 \\
\hline
\end{tabular}

*コンクリート標準示方费"の式(6.3.8),ただし $\gamma_{b}=1$, による。 （輪荷重接地面 $(15 \mathrm{~cm} \times 8 \mathrm{~cm})$ を使用）
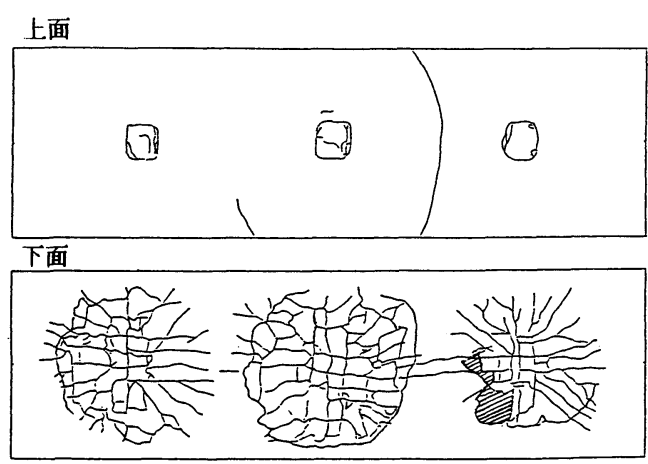

図一5 静的破堙モード（供試体 ISS）
表一 5 に示す. 表中，各数字の右肩に*印を付けたもの は破壊荷重より小さい荷重で $1 \times 10^{4} \sim 2 \times 10^{4}$ 回程度の 反復走行の後のデータである. 破壊荷重より小さい荷重 の先行履歴の疲労寿命に与える影響はこの表の結果から は判別できないので，この影響を考慮せず，破壊荷重と 走行回数の関係を図示したものが，図一7である. 図中, 縦軸は輪荷重の静的破壊荷重（表一4）に対する比で表 わしている，結果はかなりばらついており，定量的な結 論を見出しがたいが，表一5 と図一7を合わせて考えれ ば，以下の点が指摘できる.

1）厚さ $75 \mathrm{~mm}$ の供試体 ISS は同一配筋の厚さ 72

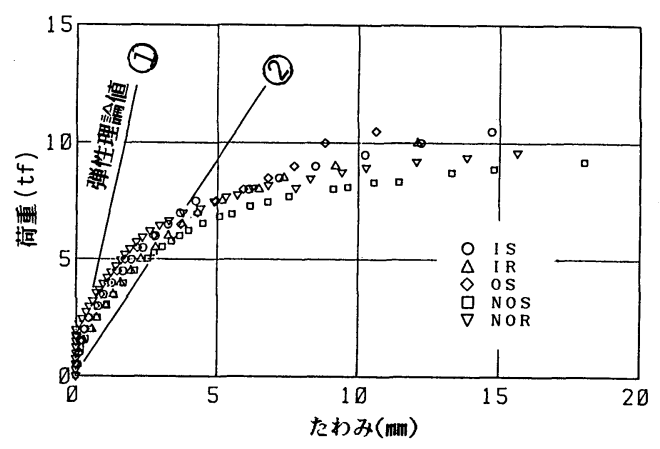

図一6 床版中央点でのたわみ

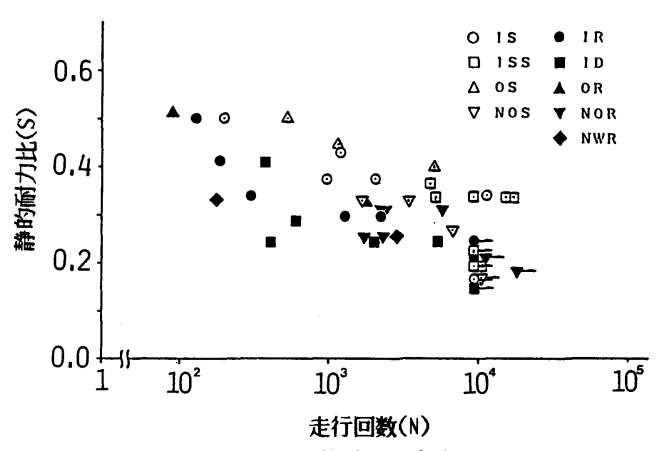

図一7 疲労耐力と寿命

表一5 走行実験における疲労耐力と寿命

\begin{tabular}{|c|c|c|c|c|c|c|c|c|c|}
\hline \multirow{2}{*}{$\begin{array}{c}P \\
(t f)\end{array}$} & \multicolumn{9}{|c|}{ 供 試 体 } \\
\hline & I S S & I S & IR & I D & OS & OR & NOS & NOR & NWR \\
\hline $5.0^{\Delta 1}$ & $5155^{* 1}$ & 195 & 126 & 369 & 538 & - & - & - & $\overline{-}$ \\
\hline 4.5 & $\begin{array}{r}5522^{* 2} \\
10723^{* 3} \\
17061^{* 4} \\
19297^{* 5}\end{array}$ & 1238 & - & - & 1231 & - & - & - & - \\
\hline 4.0 & - & $\begin{array}{c}970 \\
2134^{* 6}\end{array}$ & 165 & - & 5491 & 87 & - & - & - \\
\hline 3.5 & $* 5$ & 12401 & 291 & 599 & - & - & - & - & - \\
\hline 3.0 & $\circledast D$ & - & $\begin{array}{l}2029 \\
1306^{* 7}\end{array}$ & $\begin{array}{c}2150^{* 8} \\
5718^{* 9} \\
392 \\
\end{array}$ & - & - & $\begin{array}{l}3628^{* 11} \\
1842 * 11\end{array}$ & $\begin{array}{l}2345 \\
2455^{* 22} \\
6435^{* 13}\end{array}$ & 168 \\
\hline $2.5^{\Delta 2}$ & $\$ 2$ & - & $\approx 7$ & (9) & - & 1084 & 7415 & $\begin{array}{l}1775 \\
2409^{* 44}\end{array}$ & 3000 \\
\hline $2.0^{\Delta 8}$ & (*3) & - & - & - & - & - & (II) & (13) & - \\
\hline $1.7^{4}$ & - & (6) & - & $* 8$ & - & - & 10 & $\frac{710}{14}$ & - \\
\hline
\end{tabular}

(注) $\Delta 1$ : I S では5.2tf、 $\triangle 2:$ NWR では2.4tf、I S S では2.6tf、 $\triangle 3:$ I S S では 2.2 tf 、 $\triangle 4:$ NWRでは1.6tf

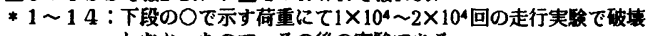
しなかったので、その後の実駼である。 
$\mathrm{mm}$ の供試体 IS より疲労耐力がかなり大きい.この原 因については後に考察するが, 静的耐力との比において も同様のことがいえるので, 疲労耐力および疲労寿命は 床版厚に大きく影響される.

2）圧縮筋を有する供試体 IR，OR，ID，NOR, NWR は王縮筋のない供試体 IS, ISS, OS, NOS より 疲労の影響を受けやすい.この原因も後に検討する.

3）短スパン $80 \mathrm{~cm}$ の供試体 NOR と $100 \mathrm{~cm}$ の供試 体 NWR での疲労耐力の差は明瞭でない.

(2)ひびわれ状況之の破壊形状

ひびわれの進展状況之破壊形状はいずれの供試体でも ほぼ同じであった．圧縮筋のない供試体 NOS, $P=2.5$ $\mathrm{tf}$ 走行時の例を図一8に示す. NOS では, 乾燥収縮に よる初期ひびわれは床版下面にわずかにみられるのみで あり, 最初に床版中央点での静的載荷時に図に示すよう な主筋および配力筋に平行なひびわれ（主筋に平行なも

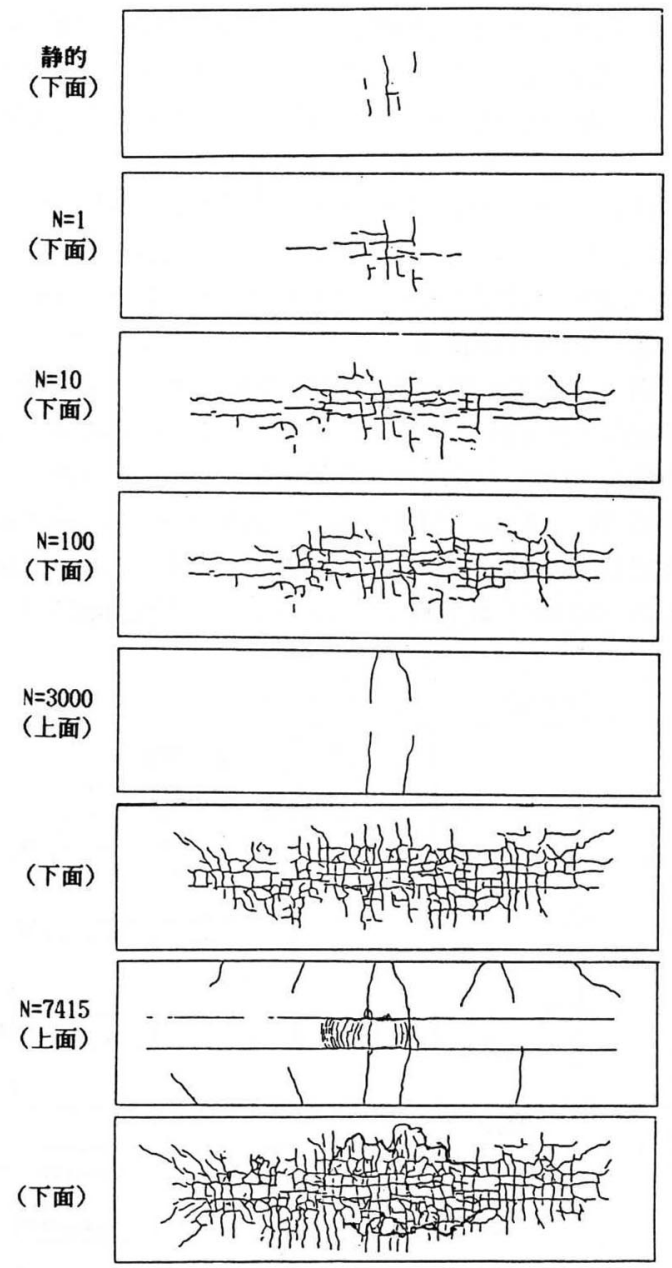

図一8 供試体 NOS $の P=2.5 \mathrm{tf}$ 走行時のひびわれ性状と破堙 形状
のの方が顕著）が発生した. 輪荷重の走行によってひび われは床版下面全域に拡がるが，初期の段階では，荷重 を取り除けば，ほとんど判別できないような微細なひび われ（中央点載荷時に観測しているので，ひびわれ図は 中央部に集中) であり, 走行回数 $(N)$ の増加とともに, ひびわれの数および幅は増大した. $N=3000$ 程度で上 面にも主筋と平行なひびわれが発生し, その後, $N=$ 7415 で破壊した。一方, 同じ時期に製作した圧縮筋の ある供試体 NOR では, 乾燥収縮により上面にも主筋に 平行なひびわれ（幅 $0.05 \sim 0.15 \mathrm{~mm}$ ) が 1,2 本，載 荷前に入っており, 荷重 $P=2.5 \mathrm{tf}$ の走行回数の増加と ともに, 上, 下面のひびわれは拡大し, $N=1775$ で破 壊した。

最終的な破壊はいずれの供試体でもコンクリート断面 のせん断破壊を伴って起こった. 破壊形状は図一8に示 すように通常の押抜きせん断形に類似していたが, 実験 終了後に断面を調べたところ短スパン方向の断面内の破 壊面は写真一 2 に示すようにほぼ $45^{\circ}$ 方向に拡がってい たが, 短スパン直角方向 (車輪の進行方向) の断面内の 破壊面は明確に判別できなかった.

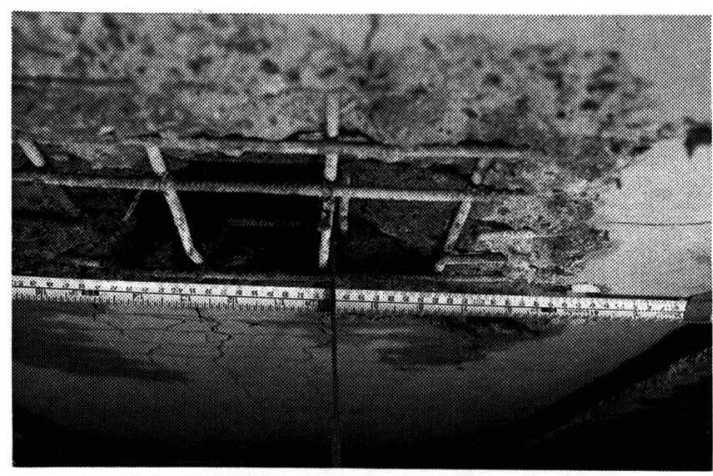

写真一2 破埭断面（配力筋方向に撮影）

(3) たわみ形状

たわみは, 所定の走行回数の後に車輪を床版中央点に 止め, 除荷時と載荷時の両方で測定した. 走行回数 $(N)$ と床版中央点のたわみ $(\delta)$ との関係を図一 9 に示す. 図中, 総たわみとは弾性たわみと残留たわみ（塑性たわ み）の和を意味する. 1 回の走行 $(N=1)$ で, 総たわ みは静的載荷時（図一6参照）の約 1.3 倍まで増加し， その後, 走行回数が増すにつれて弾性たわみと残留たわ みはともに徐々に増加するが，弾性たわみの増加率が 残留たわみの増加率に比べて緩慢であった．破壊直前 になって急激に両たわみとも増加した，破壊の位置は一 定していないので, 比較が正確でないが, 破壊直前の総 たわみは短スパン $80 \mathrm{~cm}$ の供試体で，3〜 $6 \mathrm{~mm}$ であり， 静的載荷時の $15 \sim 25 \mathrm{~mm}$ に比べて走行荷重時の方が曲 
げ変形が少なく，せん断破壊が起こりやすいと結論づけ られる．破壊したすべての供試体について，破壊直前の 弾性たわみを引張コンクリート部を無視した断面剛性

(鋼とコンクリートの弾性係数比 $(n)$ は 15 , 圧縮筋は 無視）をもつ直交異方性弾性薄板理論値に対する比で整 理したものが図一10である. 図中, 横座標は設計荷重 相当値 $\left(P_{d}\right)$ に対する輪荷重 $(P)$ の比である. 図より, 破壊直前の弾性たわみは上述の理論値の $0.5 \sim 1.8$ 倍の 範囲にあり，平均値 1.05 , 分散 0.09 である.

一方, 残留たわみ $(\delta)$ について, $\delta-\log N$ 曲線はあ る走行回数 $\left(N_{s}\right)$ まではほぼ直線であり, $N_{s}$ 以後は勾

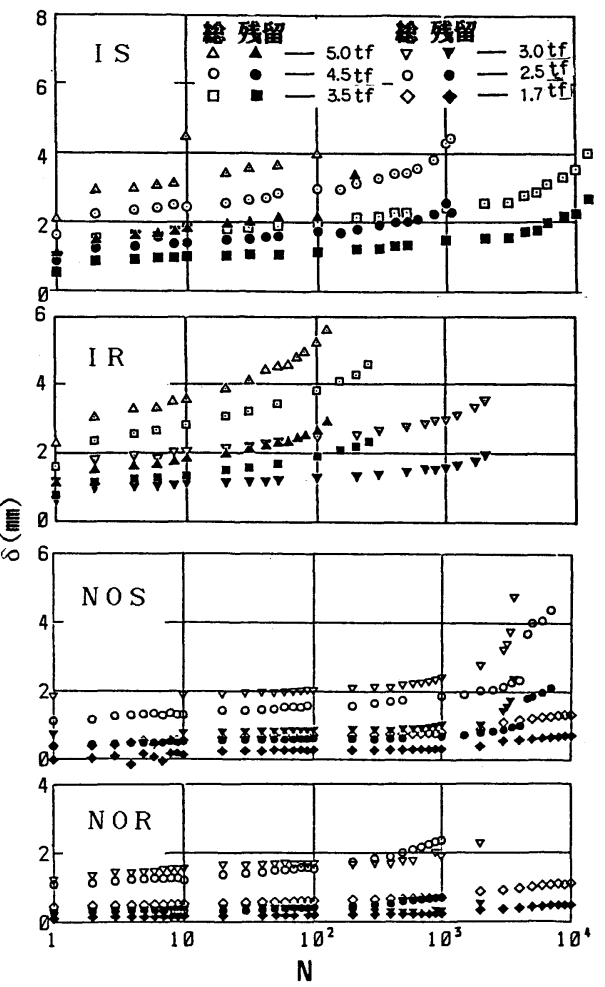

図一9 走行回数 $(N)$ と中央点たわみ $(\delta)$ の関係

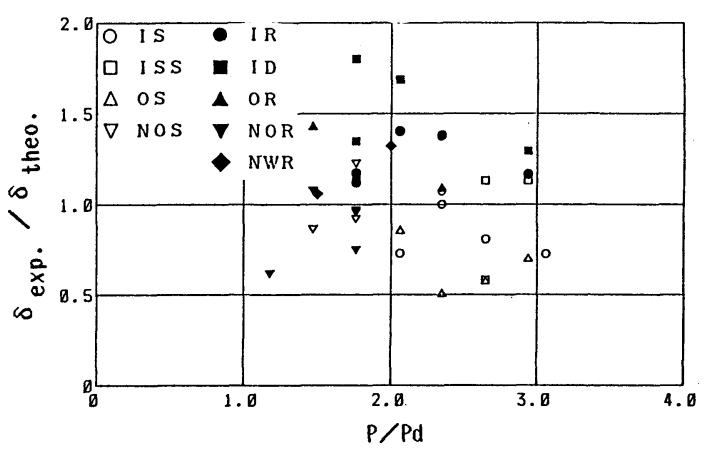

図一10 破壊直前の弾性たわみの理論值に対する比
配が加速度的に増加し，押抜きせん断破壊に至っている. すなわち， $N_{s}$ 以前の挙動はひびわれ面の磨耗によるコ ンクリートの微粉の落下やひびわれの角の欠落(角落ち) などの観察に対応しており， $N_{s}$ 以降はかぶり部コンク リートの剝落やひびわれ面の段差の発生などの観察に対 応している．したがって， $N_{s}$ までは，曲げひびわれの 進展領域であって， $N_{s}$ を越えてからせん断破壊の兆候 が現われるものと推測できる.

(4) 鉄筋のひずみ性状

図一11には，床版下面中央の主筋および配力筋のひ ずみの変化を示す．各ひずみはたわみと同時に測定され ている．最初の走行での主筋のひずみが，降伏ひずみ $\left(1800\right.$ 2 $\left.000 \times 10^{-6}\right)$ を越えるような大きな荷重の下 では走行回数につれてひずみは増加し，数百回以下の走 行で破壊に至った．最初の走行での主筋のひずみが降伏 ひずみよりかなり小さい場合には，走行回数に対する主 筋のひずみの増加は緩慢であり，たわみと類似の傾向を 示している. また, 主筋の弾性ひずみは, 慣用計算值 (図 一6の理論値(2)に相当) を越えることは少ないようであ る. 一方, 配力筋のひずみは小さく, しかもその変化は ほとんゼなく増加より減少のものもみられた。

以上のことより，主筋に平行な曲げひびわれは発生す れば直ちに中立面まで進展し, その後の走行回数に対し ては, ひびわれ面の磨耗のみが促進すると推察できる.

(5) ひびわれ幅の変化

図一12 は床版中央部のひびわれ幅の走行回数に対す る変化の例を示している.ここでのひびわれ幅とは, 標 点間長 $50 \mathrm{~mm}$ の伸び計（通常 $\pi$ ゲージとよばれる）を 主筋方向に 3 個, 配力筋方向に 5 個を床版中央に直列に 配置し，この間に入るひびわれ幅の測定值の総和を主筋 間隔 $(50 \mathrm{~mm})$ 数で割ったものをいう. 測定間隔内のひ

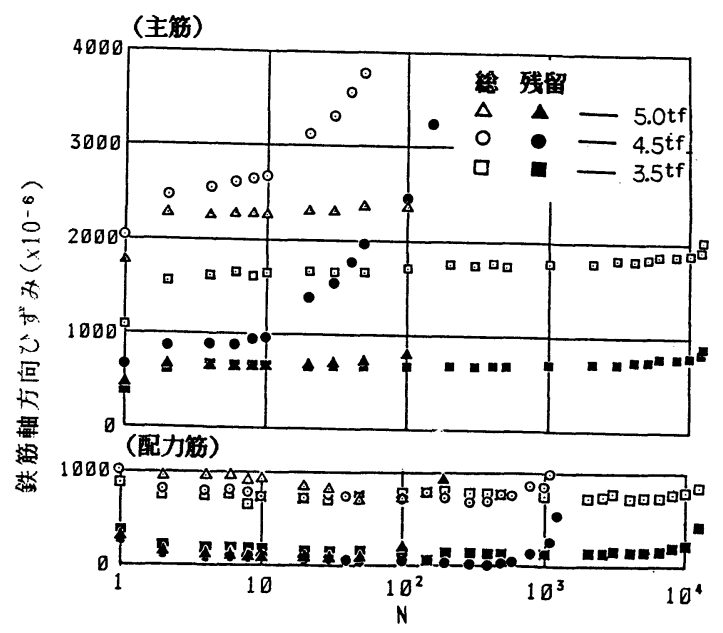

図一11 鉄筋軸方向ひずみの変化（供試体 IS） 


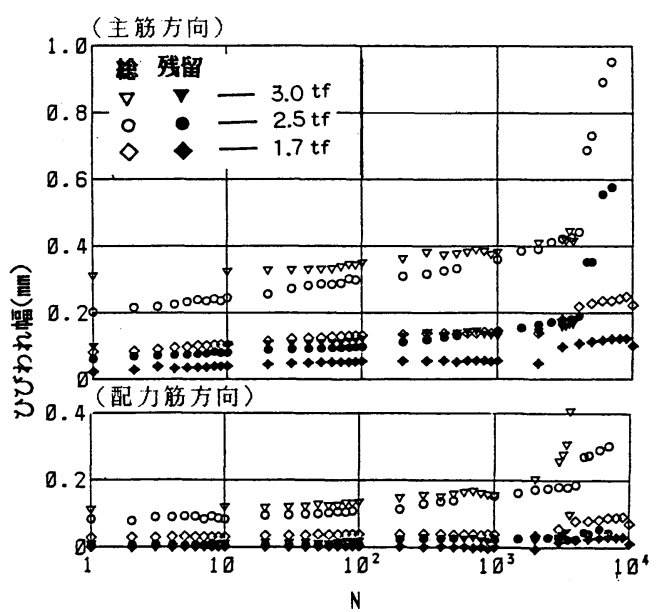

図一12 ひびわれ幅の变化（供試体 NOS）

びわれ数は各供試体において一定でないので, 測定值は 非常にばらついたが, 配力筋と平行なひびわれ幅の走行 回数に対する変化は, 図一9の残留たわみの変化之類似 した傾向を示しているが; 主筋と平行なひびわれ幅（特 にその残留値）は非常に小さかった，もちろん，図一8 に示したように,目視によるひびわれ図は格子状であり, 主筋と平行なひびわれ幅も小さくないことより, ひびわ れが開いてその幅が拡大しないのではなく，ひびわれ面 が磨耗によりスリット状になったものと推察できる。ま たこのようなひびわれのスリット化は荷重の走行回数の 増加につれて床版の下面からのコンクリートの微粉末の 落下の確認によって裏付けられた. 配力筋に平行なひび われより主筋に平行なひびわれの方がスリット化が顕著 になる原因は，主筋と平行なひびわれ面は荷重の反復走 行によってたたかれること, 両振りのせん断力を受ける ことによると思われる. またスリット化は骨材の嚙み合 い効果による床版のせん断抵抗力を低下させ，せん断力 の主筋方向への再分配を助長させ, 最終的な破壊に至る 段階では, 主筋方向に支持されたはりのようにせん断力 を受け持たされているものと推察できた.

\section{(6) 考 察}

\section{a) ひびわれ損傷度と疲労耐力}

$\mathrm{RC}$ 床版のひびわれ損傷度は一般に次の諸量によって 評価できるものと思われる.

(1) 一定荷重の下での鉄筋応力, (2)ひびわれの残留幅, (3)一定荷重の下での弾性たわみ, (4)残留たわみ. 前節の 実験結果からみれば，破壊が曲げ破壊形でないので，鉄 筋応力（ひずみ）は不適当である．また，ひびわれ幅の 残留値は定量的にとらえにくい. 剛性の低下を意味する 弾性たわみの変化は比較的緩慢であり,これによる損傷 度の評価は精度的に不利である.これに対して, 一定荷

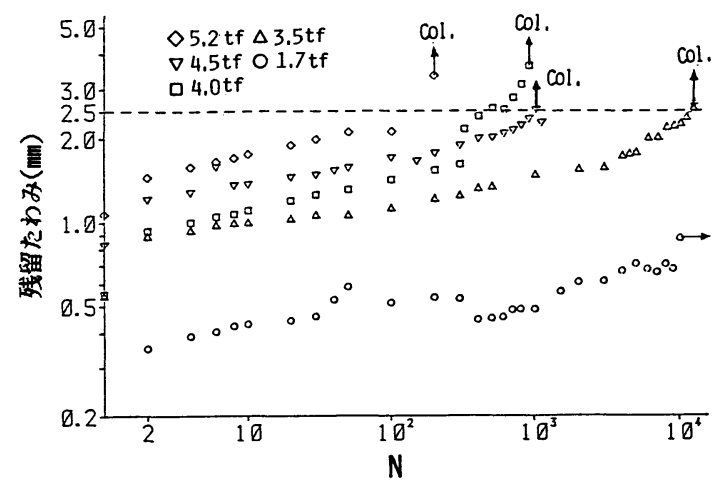

図一13 供試体IS における中央点の残留たわみの変化

重の走行繰返しの下での残留たわみは塑性変形量で, 床 版の消散エネルギー量に関係しているので, 残留たわみ による損傷度の評価が物理的にも意味があると思われ る. 図一9の例で示した残留たわみの走行回数に対する 変化を両対数グラフで書き直した例を図一13に示す. 同じ時期に製作した，コンクリート強度がほぼ同じ供試 体（IS，IR，ID，OS，OR）では，残留たわみがほぼ 同じ値（約 $2.5 \mathrm{~mm}$ ) に到達した直後に破壊した．破壊 箇所は必ずしも一定でなかったので, 破壊直前の残留た わみ值 $(\delta)$ はばらついているが， $\delta_{c r}=2.5 \mathrm{~mm}$ より小 さい範囲では $\log \delta$ と $\log N$ の間にほぼ直線関係が認め られる.したがって, 最小二乗法によりこの直線関係 $\log \delta=\log A+B \log N$ を見出せば，表一6のように各 係数が求められる. 表中, $S$ は走行荷重の静的耐力比で, $N_{2.5}$ は得られた直線式から $\delta=2.5 \mathrm{~mm}$ に相当する走行 回数であり, Exp. は実験での破壊時の走行回数を対数 值で示している.この表より, 設計荷重相当値 $(S=0.16)$ での疲労寿命はその 2 倍の荷重での疲労寿命の $10^{5} \sim 10^{7}$

表 $6 \log \delta$ と $\log N$ の関係

\begin{tabular}{|c|c|c|c|c|c|}
\hline & $\mathrm{S}$ & $\mathrm{A}$ & $\mathrm{B}$ & $\log _{2.5}$ & Exp. \\
\hline & 0.49 & 1.375 & 0.1021 & 2.54 & 2.29 \\
& 0.42 & 1.100 & 0.0969 & 3.68 & 3.09 \\
I S & 0.37 & 0.859 & 0.1089 & 4.26 & 2.99 \\
& 0.33 & 0.747 & 0.1070 & 4.90 & 4.09 \\
& 0.16 & 0.344 & 0.0707 & 12.2 & - \\
\hline \multirow{4}{*}{ I R } & 0.49 & 1.320 & 0.1384 & 2.01 & 2.10 \\
& 0.34 & 1.011 & 0.1415 & 2.78 & 2.43 \\
& 0.29 & 0.863 & 0.0983 & 4.70 & 3.31 \\
& 0.24 & 0.492 & 0.1114 & 6.34 & - \\
& 0.16 & 0.420 & 0.0896 & 8.64 & - \\
\hline & 0.40 & 1.005 & 0.1367 & 2.89 & 2.57 \\
& 0.28 & 0.642 & 0.1941 & 3.04 & 2.78 \\
I D & 0.24 & 0.545 & 0.2379 & 2.78 & 2.59 \\
& 0.20 & 0.474 & 0.8442 & 10.9 & - \\
& 0.14 & 0.534 & 0.0714 & 9.39 & - \\
\hline \multirow{3}{*}{ O S } & 0.49 & 1.501 & 0.0745 & 2.98 & 2.29 \\
& 0.44 & 1.075 & 0.0936 & 3.91 & 3.08 \\
& 0.39 & 1.033 & 0.0651 & 5.90 & 3.74 \\
\hline O R & 0.50 & 0.828 & 0.2625 & 1.83 & 1.94 \\
& 0.32 & 0.307 & 0.2724 & 3.35 & 3.04 \\
\hline
\end{tabular}


表一7 $N=1$ および $N=10^{4}$ 時の耐力

\begin{tabular}{|c|l|c|c|c|c|}
\hline & $\begin{array}{l}\text { Crite- } \\
\text { rion }\end{array}$ & $S(N=1)$ & $S\left(N=10^{4}\right)$ & $A^{*}$ & $B^{*}$ \\
\hline \multirow{2}{*}{ I S } & $\log _{2.5}$ & 0.5253 & 0.4011 & 0.5253 & -0.0311 \\
& Exp. & 0.6658 & 0.3277 & 0.6658 & -0.0845 \\
\hline \multirow{2}{*}{ I R } & $\operatorname{logN}_{2.5}$ & 0.5139 & 0.3424 & 0.5139 & -0.0429 \\
& Exp. & 0.7468 & 0.1751 & 0.7468 & -0.1429 \\
\hline \multirow{2}{*}{ O S } & $\log _{2.5}$ & 0.5799 & 0.4486 & 0.5799 & -0.0328 \\
& Exp. & 0.6489 & 0.3737 & 0.6489 & -0.0688 \\
\hline \multirow{2}{*}{ O R } & $\operatorname{logN2.5}$ & 0.7167 & 0.2430 & 0.7167 & -0.1184 \\
& Exp. & 0.8175 & 0.1629 & 0.8175 & -0.1636 \\
\hline
\end{tabular}

倍になっており，損傷度で表わせば，設計荷重の 2 倍の 荷重の 1 回走行が床版に与える損傷度は設計荷重の 1 回 走行時の損傷度の $10^{5} \sim 10^{7}$ 倍に相当するといえる. 次 に, 表一6 の結果を再度回帰分析し， $N=1$ および $N=$ $10^{4}$ 時の耐力 $(S)$ を $S=A^{*}+B^{*} \log N$ で予測したもの が表一7である。表中，Exp. は図一7のデータから各 供試体に対して直接に最小 2 乗法により求めた值であ る. 表の結果より荷重の 1 回走行時の耐力 $(N=1$ で破 壊する荷重）は床版の静的耐力の 50 ～ $80 \%$ であるとい える.

\section{b）圧縮筋の疲労耐力に与える影響}

すでに述べたように，圧縮筋のある供試体の方が圧縮 筋のない供試体よりも疲労耐力が小さい。このことは表 一7からもいえる.すなわち, 静的耐力は両者でほとん ど変わらないのに, $N=10^{4}$ での耐力は明らかに後者の 方が低い。この原因は(1)圧縮筋の存在によりコンクリー トの有効せん断断面が減少する，(2)圧縮筋の拘束により コンクリートの乾燥収縮による引張応力または初期ひび われが顕著になる，等が考えられる．(1)については明確 に結論しがたいが, 走行荷重の繰返しの下では静的破壊 時のような大きな塑性変形を伴わないので, 鉄筋のダウ エル効果が期待できず，曲げ圧縮領域のコンクリートに よって主として受け持たれるせん断抵抗力が圧縮筋の存 在によって低下すると考えられる．次に(2)については， 明らかに圧縮筋のある供試体の方が初期ひびわれが多 かった．同じ時期に製作した供試体で，圧縮筋のない NOS では下面のみにごく微細なひびわれが観測された だけであったが，圧縮筋のあるNOR では上面にも 1 ， 2 本の主筋と平行に幅 $(0.05 \sim 0.15 \mathrm{~mm})$ のひびわれが, ほとんどの供試体に観察された。床版厚が特に小さい

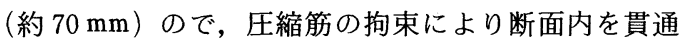
するひびわれが容易に入るものと思われ，貫通ひびわれ をもつ床版では走行荷重の繰返しによってひびわれ面の 磨耗は早期に助長され，床版断面のせん断抵抗が急速に 減少するものと推察される.

c）疲労破壊のメカニズム

実験結果の節で述べたように，比較的大きな荷重の走 行の下で主筋は降伏し，床版は数百回以下の走行回数で
破壊に至っている，一方，設計荷重相当値の 2 倍以下の 比較的小さい荷重の走行の下では主筋は降伏に至らず, 鉄筋ひずみはほとんよ゙変化せずに，ひびわれの数や幅お よびたわみが増加し，床版は破壊に至った。

走行荷重を受ける床版の曲げ破壊について, 理論的に は，莪増漸増崩壊（Incremental collapse）之交番塑性 崩壊（Cyclic plastic collapse）が考えられる. 実験床 版は周辺で単純支持されているのでごく少ない走行回数 での破壊は派増漸増崩壊が先行したものと推察される.

E. Melan ${ }^{7)}$ によれば，「ある大きさの荷重 $(P)$ の走行 繰返しの下で発生する弾性モーメントを $M_{i j}^{e}$ とすれば, $M_{i j}^{e}+M_{i j}^{r}$ が床版のいたるところで降伏条件を侵さない で，時間に依存しない一定の $M_{i j}^{r}$ が存在するならば, この床版は変形硬化 (Shakedown) する（すなわち， 弾性挙動を繰り返す) であろう」という。これより, 変 形硬化荷重 $\left(P_{s d}\right)$ の決定は次の問題になる.

$P_{s d}=$ maximize $P$

subject to

$\left.f\left(M_{x}^{e}+M_{x}^{r}, \quad M_{y}^{e}+M_{y}^{r}, \quad M_{x y}^{e}+M_{x y}^{r}\right) \leqq 0\right)$

ここに, $f$ は降伏関数. 実験床版は辺長 $1: 3$ の単純支 持長方形板であるが，問題を簡易化するために，幅が無 限に大きい帯状板とみなし，輪荷重は幅方向に十分な距 離を反復走行すると考えても，隅部のねじりせん断破壊 が先行しないように十分に配筋されているならば，大き な誤差を生じないであろう.すると, 問題の対称性と周 辺単純支持の条件より変形硬化するときの残留モーメン トは存在できず, 式 ( 2 ）の問題は次のようになる.

\section{$P_{s d}=$ maximize $P$}

subject to $f\left(M_{x}^{e}, \quad M_{y}^{e}, \quad M_{x y}^{e}\right) \leqq 0$

式 $(3)$ の解 $\left(P_{s d}\right)$ は荷重 $P$ を床版中央にのせたとき の弾性限界荷重に等しい。すなわち, 床版の弾性主モ一 メントの最大値が断面の終局モーメント $\left(M_{u}\right)$ に等し くなるときの荷重が $P_{s d}$ になる.コンクリート標準示方 書 ${ }^{1}$ に従って $M_{u}$ を計算し, 供試体に対する $P_{s d}$ を求め れば，表一8を得る. 配力筋が少ない供試体では, 配力 筋方向の終局曲げモーメントによって $P_{s d}$ が決まってい るが，実験結果の節で述べていたように，配力筋の応力 は非常に小さいことを考慮して, 主筋方向の終局曲げ モーメントを基準にした変形硬化荷重 $\left(\bar{P}_{s d}\right)$ を計算す れば，表一8の（）内の值を得る．表より，鉄筋の降 伏強度が他より大きい供試体 ISS の疲労耐力が他より 大きくなっていることの理由の 1 つは変形硬化荷重の相 違によると思われる.

次に, 変形硬化荷重より小さい走行荷重の絽返しでの 床版の破壊について考える，すでにb)(5)で述べたよう に, 曲げひびわれの発生後, 主筋に平行なひびわれのス リット化が輪荷重に対して板としての支持機構から主筋 
方向のはりとしての支持機構に変化させることが推察で きた.したがって,ひびわれのスリット化が十分に進行 した後には, 主筋方向のせん断力による輪荷重近傍の床 版断面の破壊が実験で観測される押し抜きせん断形の全 体破壊の引金になると考え, 以下に検討を加える.

いま，荷重 $(P)$ は単純支持長方形床版の中心にあり， これより主筋方向の距離 $(x)$ にある断面に㗢くせん断 力を $Q_{x}$ とすれば，有効幅を次式で定義する.

$$
b_{e}(x)=\frac{2}{Q_{x_{0}}} \int_{0}^{b / 2} Q_{x} d y
$$

ここに, $Q_{x_{0}}$ は $y=0$ (中心線上) での $Q_{x}$ の值, $b$ は床 版の幅である. もし, $b$ が主筋方向のスパン $(l)$ に比 して十分に大きければ, 式 $(4)$ の $b_{e}(x)$ は $P / 2 Q_{x_{0}}$ になる. $b_{e}(x)$ は $x$ の関数であり, $x=u / 2(u$ は載荷 面の幅）で最小値を， $x=l / 2$ で最大値をとる. 実験で 得られた疲労破壊面は荷重面の端部から $45^{\circ}$ 方向に拡 がっていたので, $x=u / 2+d$ ( $d$ は有効高さ)をクリティ カルな断面位置と仮定して, 単純ばりとしてせん断に抵 抗する有効幅を次式で定義する.

$$
b_{e_{0}}=b_{e}\left(\frac{u}{2}+d\right)
$$

輪荷重接地面 $(u=15 \mathrm{~cm}, v=5 \mathrm{~cm}), d=6.0 \sim 6.5 \mathrm{~cm}$ とし, 弾性薄板理論により式 (4) と式 (5) を計算す れば, $b_{e_{0}}=0.37 〜 0.38 \mathrm{~m}$ を得る.

一方，コンクリート標準示方書 ${ }^{1)}$ は，幅 $b_{e_{0}}$ をもつせ ん断補強筋をもたない $\mathrm{RC}$ ばりのせん断疲労強度式を 次式で与えている.

$$
\left.\begin{array}{l}
V_{r c d}=V_{c d}\left(1-\frac{\log N}{11}\right) \\
V_{c d}=0.9 \beta_{d} \cdot \beta_{\rho} \cdot \beta_{n} \cdot b_{e_{0}} \cdot d \cdot \sqrt[3]{f_{c d}^{\prime}}
\end{array}\right\}
$$

$f_{c d}^{\prime}$ はコンクリートの設計圧縮強度, $p$ は鉄筋比,

$$
\beta_{d}=\sqrt[4]{100 / d}, \quad \beta_{\rho}=\sqrt[3]{100 p}, \quad \beta_{n}=1
$$

実験での供試体に対する式（6）による静的せん断耐力 $\left(P_{s_{0}}=2 V_{c d}\right)$ の值を表一8に示す.すべての供試体の 中で破壊に至ったものについて, 破壊荷重 $\left(P_{f}\right)$ の $P_{s_{0}}$ に対する比と寿命 $(\log N)$ の関係を求め, 次式

$$
P_{f}=P_{s_{0}}\left(1-\frac{\log N}{11}\right)
$$

と比較したものが図一14である．この図には松井ら ${ }^{8)} の$ 実験結果も含めている，松井らのデー夕 (FA，FB) は短スパン $1.8 \mathrm{~m}$, 幅 $3 \mathrm{~m}$, 床版厚 $19 \mathrm{~cm}$, 鉄筋比約 $1.3 \%$ の単純支持長方形床版に対する輪荷重走行実験に よるものであり，破壊形状は本実験のそれと類似してお り, 供試体 FA では $b_{e_{0}}=0.87 \mathrm{~m}, \bar{P}_{s d}=54.7 \mathrm{tf}, P_{s_{0}}=$ $25 \sim 30 \mathrm{tf}$, 供試体 $\mathrm{FB}$ では $b_{e_{0}}=0.89 \mathrm{~m}, \bar{P}_{s d}=46.0 \mathrm{tf}$, $P_{s_{0}}=30 \sim 32 \mathrm{tf}$ と計算される. $\bar{P}_{s d}$ はいずれの供試体で も $P_{s_{0}}$ を上回っていることがわかる. 図一14において
表一8 各供試体に対する $\boldsymbol{P}_{s d}\left(\overline{\boldsymbol{P}}_{s d}\right)$ と $\boldsymbol{P}_{s_{0}}$

\begin{tabular}{|l|c|c|c|c|c|}
\hline \multirow{2}{*}{ 供試体 } & $\begin{array}{c}\text { I S } \\
\text { I R } \\
\text { I D }\end{array}$ & I S S & O S & N O S & NWR \\
& & O R & N O R & \\
\hline Psd(tf) & 5.02 & 6.12 & 2.43 & 3.64 & 3.35 \\
& $(5.02)$ & $(6.12)$ & $(5.02)$ & $(4.68)$ & $(4.67)$ \\
\hline Pso(tf) & 4.88 & 3.78 & 4.88 & 3.64 & 3.70 \\
\hline
\end{tabular}

着目した值

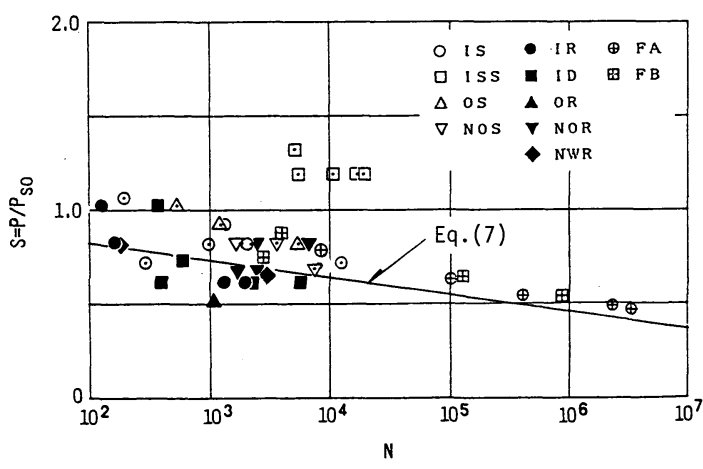

図-14 $S-\log N$ 関係

供試体 ISS をみれば，低サイクル領域での疲労耐力は $P_{s_{0}}$ のほかに $\bar{P}_{s d}$ にも影響されるようにも思われるが， 式（7）の疲労耐力式は低サイクル領域での ISS 以外 の供試体の平均值近傍と $N>10^{4}$ の高サイクル領域で実 験値と十分に整合している.

\section{3. 道路橋 RC 床版の疲労強度に対する一検討}

図一14に示したように，コンクリート標準示方書の 式 (6) は, 式 $(5)$ の有効幅 $\left(b_{e_{0}}\right)$ を用いて, 道路 橋 $\mathrm{RC}$ 床版の疲労強度の推定にも十分に使用できると 思われるので，隣接主桁で支えられた道路橋床版が主桁 と平行な自動車の後輪荷重を床版中央線上に受ける場合 の疲労耐力を求めてみよう. 隣接主桁間の帯状床版に作 用する荷重は道路橋示方書で規定された後輪荷重（作用 面 $50 \mathrm{~cm} \times 20 \mathrm{~cm})$ とし, 主析間長である床版のスパン は $l=2 \mathrm{~m}, 2.5 \mathrm{~m}, 3 \mathrm{~m}$, 床版の有効高さは $d=14 \mathrm{~cm}$, $18 \mathrm{~cm}, 22 \mathrm{~cm}$ としたときの式 $(5)$ による有効幅 $\left(b_{e_{0}}\right)$ と式 ( 7$)$ による静的せん断耐力 $\left(P_{s_{0}}=2 V_{c d}\right)$ を $f_{c d}^{\prime}$ $=240 \mathrm{kgf} / \mathrm{cm}^{2}, \quad p=0.015$ (単鉄筋等方配筋) と仮定し て計算すると表一 9 を得る. 表の結果, $P_{s_{0}}$ はスパンの 影響はほとんど受けず， $d$ が大きくなるにつれて大幅に 増加していることがわかる.

次に, 式 (6) による床版の疲労耐力 $\left(P_{f}\right)$ は, $N$ $=2 \times 10^{6}$ のとき $0.43 P_{s_{0}}$ になる. また, 道路橋示方書 に基づく設計後輪荷重 $(P=9.6 \mathrm{tf})$ の下で主筋応力が 許容応力 $\left(\sigma_{s a}=1400 \mathrm{kgf} / \mathrm{cm}^{2}\right)$ になる床版の疲労寿命 を式（6)，（7）より求めてみると，表一10を得る. 
表一9 $\quad \boldsymbol{b}_{e_{0}}(\mathrm{~m})$ と $\boldsymbol{P}_{s_{0}}(\mathrm{tf})$ の各值

\begin{tabular}{|c|l|l|l|l|l|l|}
\hline \multirow{2}{*}{$\mathrm{d}(\mathrm{cm})$} & \multicolumn{6}{|c|}{$l(\mathrm{~m})$} \\
\cline { 2 - 7 } & \multicolumn{2}{|c|}{2.0} & \multicolumn{2}{c|}{2.5} & \multicolumn{2}{|c|}{3.0} \\
\hline 14 & 1.02 & 27.4 & 1.05 & 28.2 & 1.06 & 28.5 \\
18 & 1.14 & 39.4 & 1.17 & 40.5 & 1.18 & 40.8 \\
22 & 1.19 & 50.0 & 1.23 & 50.6 & 1.25 & 51.4 \\
\hline
\end{tabular}

表一10 $P_{s_{0}}(\mathrm{tf})$ と $\log N$ の各值

\begin{tabular}{|c|l|l|l|l|l|l|}
\hline \multirow{3}{*}{$\mathrm{d}(\mathrm{cm})$} & \multicolumn{6}{|c|}{$l(\mathrm{~m})$} \\
\cline { 2 - 7 } & \multicolumn{2}{|c|}{2.0} & \multicolumn{2}{c|}{2.5} & \multicolumn{2}{|c|}{3.0} \\
\hline 14 & 23.6 & 6.53 & 25.1 & 6.79 & 25.8 & 6.91 \\
18 & 28.5 & 7.29 & 30.1 & 7.49 & 31.0 & 7.59 \\
22 & 30.8 & 7.57 & 32.7 & 7.77 & 33.9 & 7.88 \\
\hline
\end{tabular}

明らかに同じ曲げ強度をもつ床版でも，有効高さが大き くなれば，疲労寿命が伸びることがわかる．また，疲労 寿命に与える床版スパンの影響はあまり現われていない が，本研究では，ひびわれ荷重よりはるかに大きい輪荷 重のみを考慮していることに留意されたい.

\section{4. 結 論}

本研究で得られた結論を以下に列挙する.

（1）すべての実験床版は静的荷重および走行荷重の いずれにおいてもコンクリート断面のせん断によって最 終的に破壊し，破壊時には鉄筋の破断を伴わなかった。

（2）同じ鉄筋量の床版の疲労耐力は床版の厚さに大 きく影響された.

（３）圧縮筋を有する床版は有しない床版より疲労寿 命は短かった．この主たる原因は圧縮筋の拘束によって 発生するコンクリートの乾燥収縮によるひびわれが床版 の初期欠陥として作用したものと考えられた。

（4）破壊直前の弾性たわみ（中央点載荷によるたわ み）は引張部コンクリート無視の直交異方性弾性薄板理 論伹の $0.5 \sim 1.8$ 倍（平均値 1.05 , 分散 0.09）であった.

（5）荷重の走行の床版の破壊に与える影響は非常に 大きい.すなわち, 荷重の 1 回走行時の床版の耐力は床 版中央の静的耐力の $50 \sim 80 \%$ に減少した。

（6）設計荷重相当値の 2 倍程度以下での荷重の走行 繰返しでは，鉄筋の応力はあまり変化せず，また配力筋 の応力は RC ばりの慣用設計値よりかなり小さい.

（7）荷重の走行によって床版下面のひびわれの数お よび幅が増加したが，特に主筋と平行なひびわれ幅は断 面の変形のみではなく，ひびわれ面のコンクリートの磨 耗によっても大きくなった。

（8）ひびわれ面のコンクリートの磨耗によってス リット化したひびわれをもった床版は配力筋方向のせん
断抵抗を失い作用せん断力に対する支持機構は荷重の走 行回数が増加するにつれて主筋方向のはりとしての機構 に変化し, 最終的にはある有効幅 $\left(b_{e_{0}}\right)$ をもつはりと してのせん断破壊に床版は支配されると推察できた.

（9）上記の $b_{e_{0}}$ を弾性薄板理論を用いて求め, コン クリート標準示方書のせん断補強筋をもたないはりのせ ん断疲労強度式を適用することにより, 荷重の走行回数

(N) が $10^{4}$ 以下の低サイクル領域での床版の疲労耐力 の平均値付近と $N$ が $10^{4}$ 以上の高サイクル領域での松 井ら ${ }^{8}$ による疲労耐力の実験值を十分に予測できた.

（10）道路橋示方書により設計された $\mathrm{RC}$ 床版に対 して，上記のせん断疲労強度式を適用すれば，許容応力 度設計法による同じ曲げ強度をもつ床版でも有効高さが 大きくなれば疲労寿命が伸びることがわかった。

最後に, 本研究の一部に対して昭和 56 年, 57 年度お よび昭和 59 年度, 60 年度文部省科学研究費補助金 (一 般研究 $(\mathrm{C}))$ を受けたこと, さらに実験床版の製作に あたっては，阪神高速道路公団保全技術部の協力を得た ことを付記し，感謝の意を表したい。

\section{参 考 文 献}

1）コンクリート標準示方書（昭和 61 年度版）設計編, 土木 学会, 1986 年 10 月.

2）倉田・園田・実松・竹村：既設道路 $\mathrm{RC}$ 床版の疲労破壊 実験と疲労破壊機構に関する一考察, 第 22 回構造工学シ ンポジューム, 日本学術会議, pp. 63 70, 1976 年 1 月.

3）岡村・園田：ひびわれ床版の力学特性, 鉄筋コンクリー 卜床版疲労設計委員会報告「鉄筋コンクリート床版の損 傷と疲労設計へのアプローチ」, 土木学会関西支部, pp. $75 \sim 112,1977$ 年 7 月.

4) Okada, K., Okamura, H. and Sonoda, K. : Fatigue Failure Mechanism of Reinforced Concrete Bridge Deck Slabs, Transportation Research Record 664, TRB, Washington, D. C., pp.136 144, 1978.

5） 岡田・岡村・園田・島田：道路橋鉄筋コンクリート床版 のひびわれ損傷と疲労性状, 土木学会論文報告集, 第 321 号, pp. 49 61, 1982 年 5 月.

6）今井・岡田・児島・水元：鉄筋コンクリート床版の乾燥 収縮ひびわれに関する研究, 土木学会論文報告集, 第 340 号, pp. 175 184, 1983 年 12 月.

7) Melan, E. : Theorie statish unbestimmeter syteme, Prelim. Publ. of 2 nd. Congr. of IABSE, Berlin, pp. 43 $64,1936$.

8) Matsui, S., Okamura, H., Sonoda, K. and Okada, K. : Concepts for Deterioration of Highway Bridge Decks and Fatigue Studies, International Symposium of Fundamental Theory of Reinforced and Prestressed Concrete, Nanjing, China, 1986.

(1987.2.19·受付) 